\title{
Formulation and Shelflife Evaluation of Kodo Millet Incorporated Ready to Cook Mixes
}

\author{
A. Mohana Vidhya* and M. Roobhadevi \\ Department of Foods and Nutrition, Vellalar College for Women, Erode, Tamil Nadu, India; \\ suprithahari2009@gmail.com
}

\begin{abstract}
Minor millets are recognized as important substitute for major cereal crops to cope up with worldwide food shortage and to meet the demand of increasing population of both developing and developed countries [1]. Kodo millet is highly nutritious but has received little attention in terms of product utilization. Supplementation of millets in cereal based products have become increasingly popular due to nutritional and economic advantages. They are considered as a shield against nutritional deficiency disorder and provide nutritional security [2]. Hence the present study was done to formulate and standardize ready to cook mixes with incorporation of kodo millet at $10 \%, 20 \%$ and $30 \%$ respectively and to assess the shelf life of formulated ready to cook mixes. Results showed that recipes prepared out of ready to cook mixes with incorporation of kodo millet was highly acceptable. Shelf life evaluation showed that microbial load was within safe limit in the kodo millet incorporated ready to cook mixes upto 45 days.
\end{abstract}

Keywords: Convenience Food, Formulation, Kodo Millet Flour, Shelf Life Evaluation, Value Addition

\section{Introduction}

Minor millets are the staple food of the poor farmers and agricultural labourers. Millets are used to substitute to wheat and rice due to good functional properties in food application, high nutritional quality and abundant availability [3]. Apart from value addition by processing to traditional products from these grains, development of newer products offers variety, convenience, quality, cost efficiency and scope for increasing the nutritive value. Kodo millet is rich in phenolics, tannins and phytates which act as an antioxidant [4]. The beneficial role of millet based diet is to protect the body against oxidative stress and maintaining blood glucose level in Type II diabetes mellitus[5].

Nutritious, variety and taste are the key trends in the convenience food segment. The growth in the consumption of convenience foods is due to several socioeconomic developments. One main factor is the change in lifestyle which has come in recent years due to higher disposable incomes, also the popularity of Indian cuisine is spreading globally and as such the international markets are also showing good demand for such foods [6]. The fibre content of kodo millet is very high. Kodo millet has around $11 \%$ protein and the nutritive value of protein has been found to be comparable of other small millets. As with other food grains, the nutritive value of kodo millet protein could be improved by supplementation with legume protein [7].

So, based on all these facts, the present study was undertaken to formulate and standardize ready to cook mixes with incorporation of kodo millet and organoleptically evaluvate the receipes prepared out of ready to cook mixes and to assess the shelf life of formulated ready to cook mixes.

${ }^{*}$ Author for correspondence 


\section{Materials and Methods}

Good quality kodo millet was procured from Agricultural University, Coimbatore. Kodo millet was processed to flour by various steps viz, cleaning, winnowing, soaking in cold water for 24 hours, steaming for 20 minutes, drying and milling. The processed millet flour was analysed for crude fibre, iron, phosphorus, moisture, protein and calcium contents by standard methods [8]. The prepared kodo millet flour was used in the formulation of ready to cook mixes at $10 \%, 20 \%$ and $30 \%$ level.

\subsection{Preparation of Standard Ready to Cook Mixes}

Various ready to cook mixes such as Weaning mix, Murukku mix, Sevai mix, Adai mix and Dosa mix were prepared. The ingredients used for the formulation are as follows.

- Weaning mix

Weaning mix was prepared using ragi, bajra, wheat, rice, maize, groundnut, almond, elachi, roasted bengalgram and jaggery.

- Murukku mix

Ingredients such as parboiled rice, raw rice, Bengalgram dhal, black gram and dry chillies were used in the preparation of murrukku mix

- Sevai mix

In the preparation of sevai mix, rice and salt were used.

- Adai mix

Adai mix were prepared using rice flour, greengram, redgram dhal, blackgram dhal, Bengalgram dhal, curry leaves, dry chillies and cumin seeds.

- Dosa mix

Wheatflour and salt were used in the preparation of dosa mix.

\subsection{Variations of Kodo Millet Incorporation}

- Instead of rice, kodo millet was incorporated at $10 \%, 20 \%$ and $30 \%$ levels in the preparation of weaning mix, murukku mix, adai mix and sevai mix.

- Instead of wheat, kodo millet was incorporated at $10 \%$, $20 \%$ and $30 \%$ levels in the preparation of dosa mix.
By using ready to cook mixes, various receipes such as Nutrient ball, Murukku, Sevai, Adai and Dosa were developed by standard procedures and subjected to sensory evaluvation. For organoleptic evaluation, five- point numerical scoring test were used to sense the parameters like colour, texture, taste, flavor and appearance of food products with the help of 20 semi trained panel members. Contribution of nutrients in the prepared ready to cook mixes (highly accepted) was calculated per 100g using Nutritive Value of Indian Foods, ICMR [9]. Ready to cook mixes were stored in plastic airtight containers and tested for their microbial load at initial, $15^{\text {th }}, 30^{\text {th }}$ and $45^{\text {th }}$ day of storage. The data obtained was analysed statistically by t-test.

\section{Results and Discussion}

\subsection{Nutrient Content of Kodo Millet Flour}

The processed kodo millet flour contains $9.7 \mathrm{~g}$ protein, $34.3 \mathrm{mg}$ calcium, $173 \mathrm{mg}$ phosphorus, $0.6 \mathrm{mg}$ iron and $10 \mathrm{~g}$ of fibre per $100 \mathrm{~g}$. The moisture content was found to be $12 \%$.

\subsection{Organoleptic Evaluation of Formulated Products}

Quality has been defined as degree of excellence and includes such things as taste, appearance and nutritional content. We might also say that quality is the composite of characteristics that have significance and make acceptability. Acceptability however, can be highly subjective [10]. The mean scores for acceptability of various recipes prepared using ready to cook mixes are given in Tables $1 \& 2$.

From the Table 1 it was revealed that 30 per cent kodo millet incorporated nutrient ball received a maximum score of 5 for colour and the highest score 4.8 were recorded for texture. The mean overall acceptability scores for nutrient ball prepared with 10, 20 and 30 per cent level of incorporation of kodo millet flour were 4.7, 4.5 and 4.9 respectively. Among the varying level of incorporation of kodo millet flour, 30 per cent level of incorporation was highly acceptable. Statistical results inferred that there was a no significant difference between standard and 30 per cent kodo millet incorporated nutrient ball.

Regarding murukku, highest score was obtained for colour (4.6) and texture (4.9) prepared with 10 per cent level of kodo millet flour incorporation. The mean overall acceptability score of murukku prepared with 10 per cent kodo millet flour incorporation was similar to that of 
Table 1. Mean scores for acceptability of nutrient ball and murukku

\begin{tabular}{|c|c|c|c|c|c|c|c|c|}
\hline \multirow{3}{*}{$\begin{array}{l}\text { Organoleptic } \\
\text { characteristics }\end{array}$} & \multicolumn{4}{|c|}{ Nutrient ball } & \multicolumn{4}{|c|}{ Murukku } \\
\hline & \multicolumn{4}{|c|}{ Level of Kodo millet Incorporation } & \multicolumn{4}{|c|}{ Level of Kodo millet Incorporation } \\
\hline & Std (a) & $10 \%(b)$ & $20 \%(c)$ & $30 \%(d)$ & Std (a) & $10 \%(b)$ & $20 \%(c)$ & $30 \%(d)$ \\
\hline Appearance & 4.7 & 4.9 & 4.4 & 4.9 & 4.7 & 4.9 & 4.3 & 4.5 \\
\hline Colour & 4.9 & 4.4 & 4.4 & 5.0 & 4.7 & 4.6 & 3.9 & 4.6 \\
\hline Flavour & 4.7 & 4.7 & 4.7 & 4.9 & 4.7 & 4.9 & 4.3 & 4.8 \\
\hline Texture & 4.9 & 4.6 & 4.6 & 4.8 & 4.7 & 4.6 & 4.3 & 4.9 \\
\hline Taste & 4.8 & 4.8 & 4.5 & 4.9 & 4.9 & 4.85 & 4.2 & 4.7 \\
\hline $\begin{array}{l}\text { Mean Overall } \\
\text { acceptability scores }\end{array}$ & 4.81 & 4.7 & 4.54 & 4.96 & 4.7 & 4.77 & 4.2 & 4.74 \\
\hline Groups compared & & $\mathrm{a} \& \mathrm{~b}$ & a \& c & a \&d & & $a \& b$ & a \& c & a $\& d$ \\
\hline 't' value & & 1.04 & $2.896^{*}$ & 0.16 & & 0.156 & $6.24^{*}$ & 0.47 \\
\hline Level of significance & & NS & $5 \%$ & NS & & NS & $5 \%$ & NS \\
\hline
\end{tabular}

Table 2. Mean scores for acceptability of sevai and dosai

\begin{tabular}{|c|c|c|c|c|c|c|c|c|}
\hline \multirow{3}{*}{$\begin{array}{l}\text { Organoleptic } \\
\text { characteristics }\end{array}$} & \multicolumn{4}{|c|}{ Sevai } & \multicolumn{4}{|c|}{ Dosai } \\
\hline & \multicolumn{4}{|c|}{ Level of Kodo millet Incorporation } & \multicolumn{4}{|c|}{ Level of Kodo millet Incorporation } \\
\hline & Std (a) & $10 \%(b)$ & $20 \%(c)$ & $30 \%(d)$ & Std (a) & $10 \%(b)$ & $20 \%(c)$ & $30 \%(d)$ \\
\hline Appearance & 4.8 & 4.7 & 4.6 & 4.6 & 5.0 & 5.0 & 5.0 & 4.9 \\
\hline Colour & 4.8 & 4.6 & 4.6 & 4.6 & 5.0 & 5.0 & 5.0 & 4.9 \\
\hline Flavour & 4.8 & 4.9 & 4.8 & 4.7 & 5.0 & 4.9 & 5.0 & 5.0 \\
\hline Texture & 4.6 & 4.6 & 4.6 & 4.5 & 5.0 & 5.0 & 5.0 & 4.9 \\
\hline Taste & 4.8 & 4.7 & 4.6 & 4.5 & 5.0 & 5.0 & 5.0 & 4.9 \\
\hline $\begin{array}{l}\text { Mean Overall } \\
\text { acceptability Scores }\end{array}$ & 4.7 & 4.7 & 4.6 & 4.6 & 5.0 & 4.9 & 5.0 & 4.9 \\
\hline Groups compared & & $\mathrm{a} \& \mathrm{~b}$ & a \& $c$ & a $\& d$ & & $\mathrm{a} \& \mathrm{~b}$ & a \& c & $a \& d$ \\
\hline 't' value & & 0.399 & 1.142 & 1.598 & & 0 & 0 & 0 \\
\hline Level of significance & & NS & NS & NS & & NS & NS & NS \\
\hline
\end{tabular}

standard and it was found to be 4.7. Statistical results inferred that there was no significant difference between standard and 10 per cent kodo milletflour incorporated murukku.

The mean scores obtained through organoleptic evaluation of sevai and dosai prepared using ready to cook mix were depicted in Table 2 . In case of colour, flavor and texture, highest score of about 4.6, 4.9, 4.6 was recorded for 10 per cent kodo millet incorporated sevai. The scores for colour and texture is slightly low, it may be due to darker colour and grainy feel of the kodo millet. Among the varying level of incorporation of kodo millet flour in sevai mix, 10 per cent level of incorporation was highly rated. Statistical results inferred that there was no significant difference between standard and 10 per cent kodo millet incorporated sevai.
Regarding dosai, 20\% kodo millet incorporated dosai received a highest score similar to that of standard for all the criteria evaluvated organoleptically. Hence it was highly acceptable. There is a slight difference in the acceptability of 10 and 20 per cent kodo millet incorporated dosa. Statistical analysis revealed that there was a no significant difference between standard and all the variation of kodo millet incorporated dosai.

\subsection{Adai}

Both standard and all the variations of kodo millet incorporated adai received a maximum score (5) for all the criteria such as appearance, colour, flavor, texture and taste used for organoleptic evaluation. Hence all the formulated products were found to be highly acceptable. 


\subsection{Comparison of Nutrients in Ready to Cook Mixes}

Nutrient content of the standard and highly acceptablekodo millet incorporated ready to cook mixes such as Weaning mix, Murukku mix, Adai mix, Sevai mix and Dosa mix were calculated with the help of ingredients used in the preparation of ready to cook mixes per $100 \mathrm{~g}$ and it was compared and its percentage loss or gain were found out. It is given in Tables 3 and 4 .

\subsection{KMF- Kodo Millet Flour}

It was revealed that there was a decrease in energy and carbohydrate contents in the kodo millet flour incorporated weaning mix and murukku mix. A slight decrease in phosphorus and iron content was noted in murukku mix and weaning mix. All the other nutrients such as protein, fibre and calcium content were increased in both weaning and murukku mix.
On comparing the nutrients in standard and kodo millet incorporated sevai mix, the nutrients such as protein, phosphorus, fibre and calcium contents were increased and a loss in energy and carbohydrate contents were observed.

Regarding dosa mix, fibre content was increased to as much as 75 per cent in $20 \%$ kodo millet incorporated dosa mix, as the fibre content of kodo millet was very high.

In adai mix, only a slight increase in fibre, calcium, phosphorus contents were found and the protein and iron contents remains the same for both standard and kodo millet incorporated adai mix.

\subsection{Microbial Load}

Microbial load of standard and highly acceptable ready to cook mixes evaluated at regular intervals for a period of 45 days is depicted in Table 5.

Table 3. Comparison of nutrients between standard and kodo millet incorporated weaning mix and murukku mix

\begin{tabular}{lcccccc}
\hline Nutrients & $\begin{array}{c}\text { Std } \\
\text { Weaning } \\
\text { Mix }\end{array}$ & $\begin{array}{c}\text { 30\% KMF } \\
\text { Weaning } \\
\text { Mix }\end{array}$ & $\begin{array}{c}\text { Percent } \\
\text { increase/ } \\
\text { decrease }\end{array}$ & $\begin{array}{c}\text { Std } \\
\text { Murukku } \\
\text { Mix }\end{array}$ & $\begin{array}{c}\text { 10\% KMF } \\
\text { Murukku } \\
\text { Mix }\end{array}$ & $\begin{array}{c}\text { Percent } \\
\text { increase/ } \\
\text { decrease }\end{array}$ \\
\hline Energy (k.cal) & 362.9 & 333.9 & -7.99 & 385 & 381 & -1.0 \\
Protein (g) & 9.98 & 10.18 & +2.0 & 10.85 & 10.85 & - \\
Carbohydrate(g) & 70.5 & 69.4 & -1.56 & 70.3 & 70.1 & -0.28 \\
Iron (mg) & 2.6 & 1.92 & -23.0 & 1.83 & 1.76 & -3.82 \\
Phosphorus(mg) & 235.8 & 239.6 & +1.61 & 215.5 & 217.3 & -0.83 \\
Fibre (g) & 1.15 & 1.84 & +60 & 1.24 & 1.44 & +16.12 \\
Calcium(mg) & 53.8 & 55.3 & +2.7 & 65.7 & 66.5 & +1.21 \\
\hline
\end{tabular}

Table 4. Comparison of nutrients between standard and kodo millet incorporated sevai mix, dosa mix and adai mix

\begin{tabular}{lccccccccc}
\hline Nutrients & $\begin{array}{c}\text { Std Sevai } \\
\text { Mix }\end{array}$ & $\begin{array}{c}\text { 10\% KMF } \\
\text { Sevai Mix }\end{array}$ & $\begin{array}{c}\text { Percent } \\
\text { Increase/ } \\
\text { decrease }\end{array}$ & $\begin{array}{c}\text { Std Dosa } \\
\text { Mix }\end{array}$ & $\begin{array}{c}\text { 20\% KMF } \\
\text { Dosa Mix }\end{array}$ & $\begin{array}{c}\text { Percent } \\
\text { increase/ } \\
\text { decrease }\end{array}$ & $\begin{array}{c}\text { Std Adai } \\
\text { Mix }\end{array}$ & $\begin{array}{c}\text { 30\% KMF } \\
\text { Adai Mix }\end{array}$ & $\begin{array}{c}\text { Percent } \\
\text { Increase/ } \\
\text { decrease }\end{array}$ \\
\hline Energy (k.cal) & 346 & 342.3 & -1.06 & 366 & 362.2 & -1.28 & 754.6 & 751.6 & -0.39 \\
Protein (g) & 6.4 & 6.5 & +1.56 & 11.5 & 10.77 & -6.95 & 59.9 & 59.9 & - \\
Carbohydrate (g) & 79 & 77.6 & -1.77 & 666 & 65.62 & -0.66 & 2890 & 2889 & -0.3 \\
Iron (mg) & 1.0 & 0.95 & -5 & 4.6 & 3.8 & -4.34 & 40.1 & 40.1 & - \\
Phosphorus (mg) & 143 & 147.5 & +3.14 & 337 & 307.6 & -8.9 & 2763 & 2766 & +0.12 \\
Fibre (g) & 0.2 & 1.08 & +440 & 1.80 & 3.16 & +75 & 84.45 & 85.1 & +0.76 \\
Calcium (mg) & 9 & 10.8 & +20 & 45.6 & 41.83 & -8.3 & 2613 & 2614 & +0.05 \\
\hline
\end{tabular}


Table 5. Microbial count of ready to cook mixes

\begin{tabular}{lcccc}
\hline \multirow{2}{*}{$\begin{array}{l}\text { Ready to cook } \\
\text { mixes }\end{array}$} & \multicolumn{4}{c}{ Bacterial count $(\mathrm{cfu} / \mathrm{g})$} \\
\cline { 2 - 5 } & Initial & $\mathbf{1 5}^{\text {th }}$ day & $30^{\text {th }}$ day & $45^{\text {th }}$ day \\
\hline Weaning mix & $3 \times 10^{6}$ & $4 \times 10^{6}$ & $4 \times 10^{6}$ & $5 \times 10^{6}$ \\
Standard 30\% KMF & $3 \times 10^{6}$ & $4 \times 10^{6}$ & $5 \times 10^{6}$ & $5 \times 10^{6}$ \\
Adai mix & $3 \times 10^{6}$ & $3 \times 10^{6}$ & $4 \times 10^{6}$ & $5 \times 10^{6}$ \\
Standard 30\% KMF & $4 \times 10^{6}$ & $5 \times 10^{6}$ & $6 \times 10^{6}$ & $6 \times 10^{6}$ \\
Murukku mix & $1 \times 10^{6}$ & $2 \times 10^{6}$ & $2 \times 10^{6}$ & $2 \times 10^{6}$ \\
Standard 10\% KMF & $1 \times 10^{6}$ & $2 \times 10^{6}$ & $2 \times 10^{6}$ & $2 \times 10^{6}$ \\
Sevai mix & $1 \times 10^{6}$ & $1 \times 10^{6}$ & $2 \times 10^{6}$ & $2 \times 10^{6}$ \\
Standard 10\% KMF & $1 \times 10^{6}$ & $3 \times 10^{6}$ & $4 \times 10^{6}$ & $6 \times 10^{6}$ \\
DosaMix & $5 \times 10^{6}$ & $7 \times 10^{6}$ & $8 \times 10^{6}$ & $9 \times 10^{6}$ \\
Standard 20\% KMF & $5 \times 10^{6}$ & $6 \times 10^{6}$ & $7 \times 10^{6}$ & $8 \times 10^{6}$ \\
\hline
\end{tabular}

It was noted that at the initial stage, the colony formation (streptococci.sp) was very low in all the ready to cook mixes and there was a slight increase in the bacterial count at the $45^{\text {th }}$ day of storage, however the levels of the bacterial count was within the recommended standards.

\section{Conclusion}

It may be concluded from the above findings, that recipes such as nutrient ball and adai were highly acceptable upto30\% of kodo millet incorporation. Dosa prepared out of wheat and kodo millet was best acceptable up to $20 \%$ of kodo millet incorporation. Murukku and sevai were found to be acceptable only up to $10 \%$ of kodo millet incorporation. Ready to cook mixes prepared out of underutilized kodo millet could enhance the nutrients fibre and calcium and reduces energy and carbohydrate contents. As a convenience food, it saves cooking time and aids in ease of preparation. On microbial analysis it was revealed that kodo millet incorporated ready to cook mixes could be effectively stored for a period of 45 days.

\section{References}

1. Sujatha R., and Josephine Immaculate J., "Evaluation of nutritive value and organoleptical changes on malted PaspalumScrobicultum L, (kodo milleti)", Journal of Food, Nutrition and Dietetics, vol. 2(3), p. 3, 2005.

2. Negalakshmi K., and Annete B.D., "Health benefits of millets" Souvenir, $3^{\text {rd }}$ International Conference on Food Technology, 7, 2013.

3. Parker R., Introduction to food science, Delmer Publication, p. 92-94, 2003.

4. Srivastara A. "Comparative study on nutritional quality of barnyard/foxtail millet kachari and traditional rice kachari", Food Technology Abstracts, vol. 41(5), p. 324, 2006.

5. Choi, and Osada, "Effects of dietary proteins of Korean foxtail millet on plasma adinopectin HDL- cholesterol, and insulin levels in genetically type-2 diabetic mice", Food Technology Abstracts, vol. 41(5), p. 106, 2006.

6. Nanditavijay, Convenience Foods, Food Digest, vol. 30, p.182-190, 2007.

7. Available: www.icisrat.com

8. Raghuramulu N., Nair K.M., and Kalyanasundaram S.A. "Manual of laboratory techniques", National Institute of Nutrition, Hyderabad. 1983.

9. Gopalan C., Sastri B.V.R., and Balasubramanian S.C., Nutritive value of Indian Foods, NIN, 2004.

10. Potter N.N., and Hotchkiss J. H., Food Science, $5^{\text {th }}$ Ed., CBS Publishers, New Delhi, 2005. 